\title{
Rare Earth Element Mineral Deposits in the United States
}



Circular 1454

Version 1.1, April 2019

U.S. Department of the Interior U.S. Geological Survey 
Cover. Rare earth elements and their uses as part of our everyday life. Photographs of minerals and high-technology devices used with permission from https://www.PEXELS.com; Rob Lavinsky, https://www.iRocks.com/; https://geology.com/. Photograph of Mountain Pass mine by Bradley Van Gosen. 


\section{Rare Earth Element Mineral Deposits in the United States}

By Bradley S. Van Gosen, Philip L. Verplanck, and Poul Emsbo

Circular 1454

Version 1.1, April 2019

U.S. Department of the Interior

U.S. Geological Survey 


\title{
U.S. Department of the Interior \\ DAVID BERNHARDT, Secretary
}

\author{
U.S. Geological Survey \\ James F. Reilly II, Director
}

\author{
U.S. Geological Survey, Reston, Virginia \\ First release: 2019 \\ Revised: April 15, 2019 (ver 1.1)
}

For more information on the USGS - the Federal source for science about the Earth, its natural and living resources, natural hazards, and the environment-visit https://www.usgs.gov or call 1-888-ASK-USGS.

For an overview of USGS information products, including maps, imagery, and publications,

visit https://store.usgs.gov.

Any use of trade, firm, or product names is for descriptive purposes only and does not imply endorsement by the U.S. Government.

Although this information product, for the most part, is in the public domain, it also may contain copyrighted materials as noted in the text. Permission to reproduce copyrighted items must be secured from the copyright owner.

Suggested citation:

Van Gosen, B.S., Verplanck, P.L., and Emsbo, Poul, 2019, Rare earth element mineral deposits in the United States (ver 1.1, April 15, 2019): U.S. Geological Survey Circular 1454, 16 p., https://doi.org/10.3133/cir1454.

\section{Library of Congress Cataloging-in-Publication Data}

Names: Van Gosen, B. S. (Bradley S.), 1960- author. | Verplanck, Philip L., author. | Emsbo, Poul, author. | Geological Survey (U.S.), issuing body.

Title: Rare earth element mineral deposits in the United States / by Bradley

S. Van Gosen, Philip L. Verplanck, and Poul Emsbo.

Other titles: U.S. Geological Survey circular ; 1454.

Description: Reston, Virginia : U.S. Department of the Interior, U.S.

Geological Survey, 2019. | Series: Circular, ISSN 1067-084X; 1454 |

Includes bibliographical references.

Identifiers: LCCN 2019016090 | ISBN 9781411342941 (paperback)

Subjects: LCSH: Rare earth metals--United States. | Rare earth

metals--Industrial applications--United States.

Classification: LCC TA480.R3 V36 2019 | DDC 553.4/940973--dc23 | SUDOC I

19.4/2:1454

LC record available at https://Iccn.loc.gov/2019016090

ISSN 1607-084X (print)

ISSN 2330-5703 (online)

ISBN 978-1-4113-4294-1 


\section{Contents}

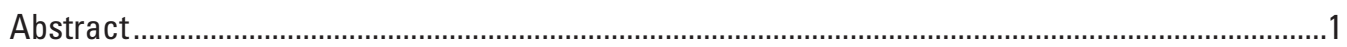

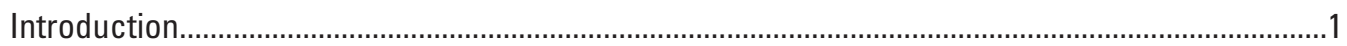

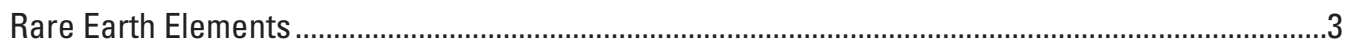

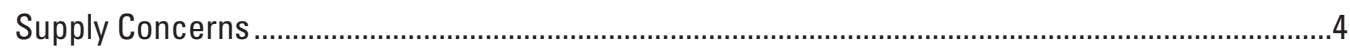

Principal Rare Earth Element Minerals in Economic Nonfuel Mineral Deposits .................................5

Rare Earth Element Mineral Deposit Types in the United States.....................................................

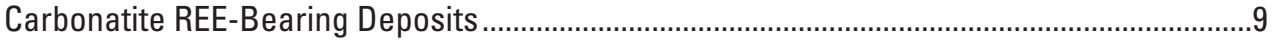



Rare Earth Elements in Sedimentary Phosphate Deposits .....................................................11

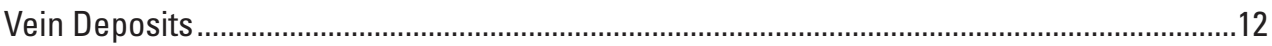

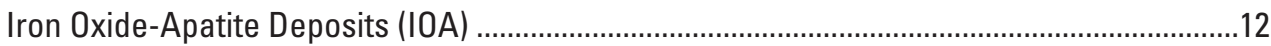

Monazite-Xenotime-Bearing Placer Deposits (Heavy-Mineral Sands) .................................12

Ion-Adsorption Clay Deposits (REE in Granite-Derived Regolith)............................................13

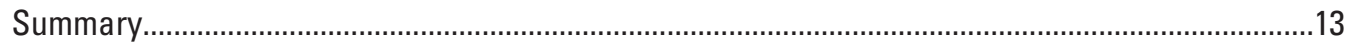

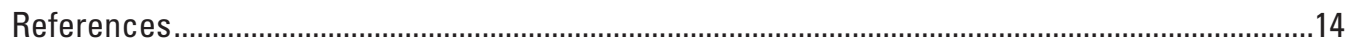

\section{Figures}

1. Rare earth elements (REEs) are used in the components of many high-technology devices that are part of our everyday life, such as those shown here ..............................

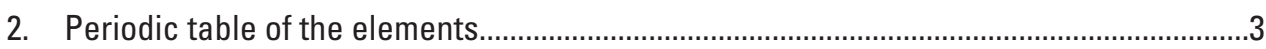

3. Mountain Pass mine, southeastern California, June 2018 ..............................................

4. Rare earth element (REE) deposits in the United States discussed in this report.............6

5. World mine production of rare-earth oxides, by country and year, from 1960 to 2012. The layers of the graph are placed one above the other, forming a cumulative total ......7

6. Principal ore minerals recovered for rare earth elements (REE) are bastnäesite, monazite, xenotime, and apatite ...................................................................................

7. Outcrop of rare earth element (REE)-rich "vein-dike" intrusions (dark vertical layers) in the Dotson zone on Bokan Mountain, southern part of Prince of Wales Island, southeastern Alaska ........................................................................................................10

8. Two-meter-thick outcrop of Upper Ordovician, high-grade REE phosphorite .................11

\section{Tables}

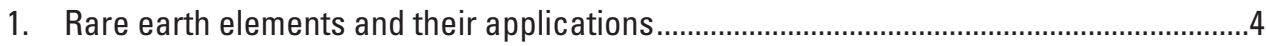

2. Principal rare earth element (REE) minerals in various economic REE deposits and their ideal chemical formula 


\section{Conversion Factors}

International System of Units to U.S. customary units

\begin{tabular}{lcl}
\hline \multicolumn{1}{c}{ Multiply } & By & To obtain \\
\hline & Length & \\
\hline meter $(\mathrm{m})$ & 3.281 & foot $(\mathrm{ft})$ \\
kilometer $(\mathrm{km})$ & 0.6214 & mile $(\mathrm{mi})$ \\
\hline & Area & \\
\hline square meter $\left(\mathrm{m}^{2}\right)$ & 0.0002471 & acre \\
square kilometer $\left(\mathrm{km}^{2}\right)$ & 0.3861 & square mile $\left(\mathrm{mi}^{2}\right)$ \\
\hline & Mass & \\
\hline metric ton $(\mathrm{t})$ & 1.102 & ton, short $\left[2,000 \mathrm{lb}^{2}\right.$ \\
metric ton $(\mathrm{t})$ & 0.9842 & ton, long $[2,240 \mathrm{lb}]$ \\
\hline
\end{tabular}

\section{Abbreviations}

$\begin{array}{ll}\mathrm{Eu} & \text { europium } \\ \mathrm{Gd} & \text { gadolinium } \\ \mathrm{HREE} & \text { heavy rare earth element } \\ \mathrm{IOA} & \text { iron oxide apatite } \\ \mathrm{km} & \text { kilometer } \\ \mathrm{La} & \text { lanthanum } \\ \mathrm{km}^{2} & \text { square kilometer } \\ \text { LREE } & \text { light rare earth element } \\ \mathrm{m} & \text { meter } \\ \mathrm{m}^{2} & \text { square meter } \\ \mathrm{Nd} & \text { neodymium } \\ \mathrm{Pm} & \text { promethium } \\ \mathrm{REE} & \text { rare earth element } \\ \mathrm{REO} & \text { rare earth oxide } \\ \mathrm{Sc} & \text { scandium } \\ \mathrm{t} & \text { metric ton } \\ \text { Tb } & \text { terbium } \\ \text { USGS } & \text { U.S. Geological Survey } \\ \mathrm{Y} & \text { yttrium } \\ & \end{array}$




\title{
Rare Earth Element Mineral Deposits in the United States
}

\author{
By Bradley S. Van Gosen, Philip L. Verplanck, and Poul Emsbo
}

\section{Abstract}

Because of their unique special chemical properties, many of the metals in the group of rare earth elements (REEs) have essential applications in 21 st century technologies. Examples of products that use REEs are cell phones, computers, fluorescent and light-emitting-diode lights, flat-screen television and computer monitors, and in high-strength magnets used by clean energy technologies such as the generators of wind turbines and batteries of hybrid and electric vehicles. REEs are used in many defense applications, such as in components of jet engines, missile guidance systems, antimissile defense systems, satellites, and communication systems.

The rare earth elements have become vital to manufacturing numerous high-tech products, which has been accompanied by a large increase in their demand. At the same time, there has been concern by the United States and many other Nations about the near-monopoly of mining, processing, and supply of REEs from one Nation, China. Between 2011 and 2017, China produced approximately 84 percent of the world's REEs, and during this time the United States only produced REEs between 2012 and 2015. The U.S. production came entirely from the Mountain Pass mine in California, providing only about 4 percent of the world REE supply. Because REEs are essential for technological applications and are primarily supplied by one Nation, there has been an increased concern in identifying new sources of REEs, including economic REE deposits.

In response to these concerns, since 2009, the U.S. Geological Survey (USGS) has conducted numerous studies focused on the distribution, geology, and potential resources for the REE-bearing mineral deposits in the United States. The basic characteristics of mineral deposit types that host REE enrichments in the United Sates are summarized in this report, with selected examples. Several types of REE-enriched mineral deposits are reviewed, including deposits in carbonatites, alkaline igneous rocks, sedimentary phosphate-rich rocks (phosphorite), regions containing REE-rich veins, iron oxide deposits containing REE-bearing apatite, monazitexenotime-bearing placer deposits (heavy-mineral sands), and ion-adsorption clay deposits (REE in granite-derived regolith). A better understanding of these mineral deposits will assist in identifying domestic resources to help alleviate the dependence on imported REEs.

The economic development of REE mineral deposits is affected by many factors beyond mining, such as commodity prices and mineral processing costs. Most of the REEs are hosted by minerals that have complex chemical formulas; this presents more challenges to process and extract the REEs. Continued advancements and refinements in mineral processing techniques may allow REE deposits with complex mineralogy to be economically developed in the future.

\section{Introduction}

Rare earth elements (REEs) have unique physical and chemical properties that have become vital to a broad range of high-technology industries (summarized in Goonan, 2011; Van Gosen and others, 2014b, 2017). The REE elements include the 15 lanthanide elements, and along with scandium and yttrium, are critical in the production of cell phones, computers, fluorescent and light-emitting-diode (LED) lights, and flat-screen monitors (televisions and computer monitors). The REEs are also fundamental components in high-strength magnets used in the generators of wind turbines and in newgeneration batteries as well as many components in hybrid and electric vehicles, all of which underpin emerging clean-energy technologies. The unique properties of REEs are indispensable to defense applications, such as in the production of jet engines, missile guidance systems, antimissile defense systems, satellites, and communication systems (U.S. Government Accountability Office, 2016) (fig. 1).

The critical role of REEs in high-tech industries has created a surge in demand and, considering there is a near-monopoly reliance on imports from a single country, have made the Nation vulnerable to supply disruptions (McCullough and Nassar, 2017; Fortier and others, 2018). This report summarizes the U.S. Geological Survey (USGS) efforts to identify and inventory U.S. sources of REEs to aid in ensuring our Nation's mineral resource needs. 

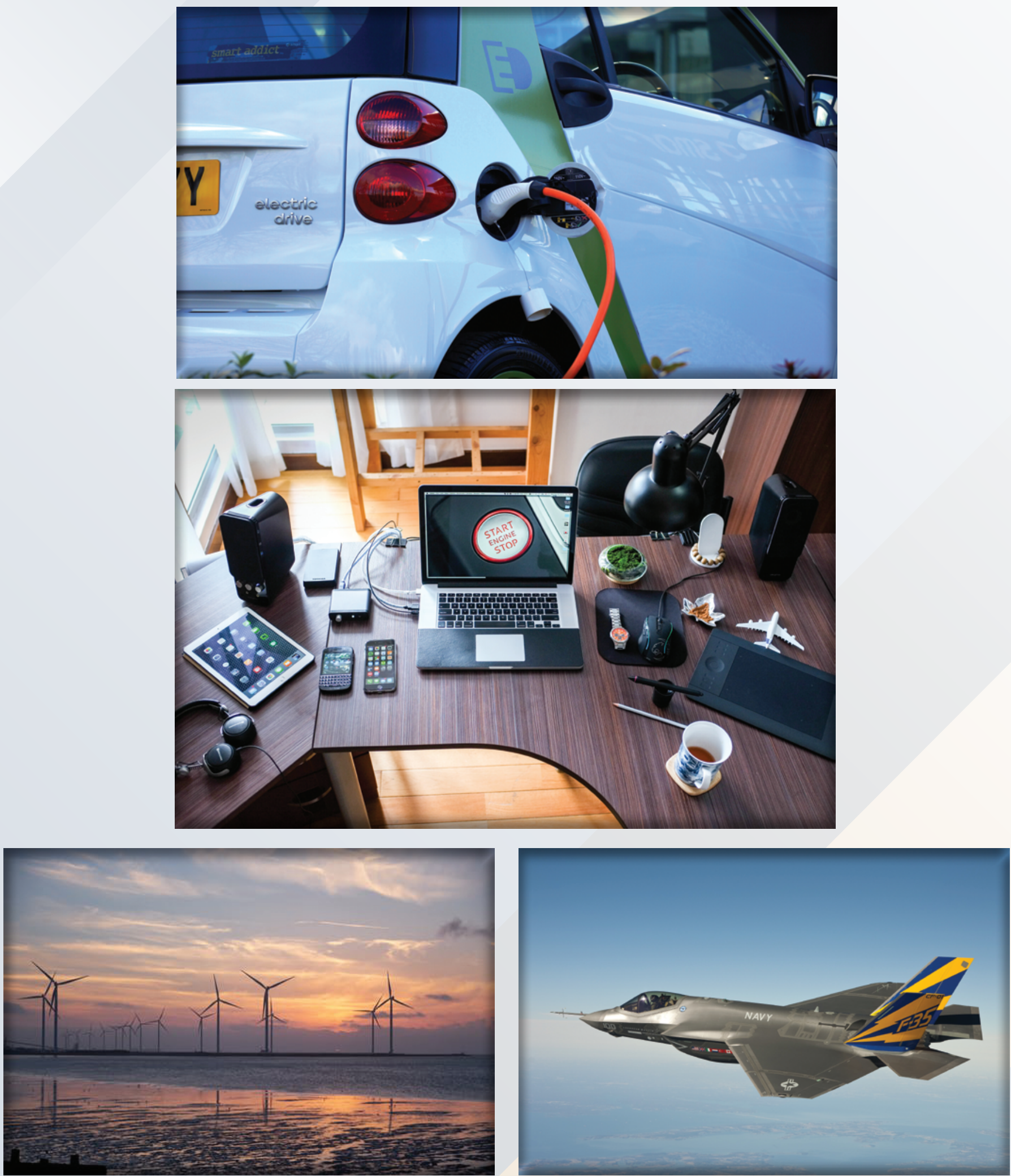

Figure 1. Rare earth elements (REEs) are used in the components of many high-technology devices that are part of our everyday life, such as those shown here. Green energy uses many REEs, including in the batteries and other modules of hybrid and electric cars, and the generators of wind turbines, which require strong permanent magnets containing neodymium-iron-boron. There are numerous defense applications of REEs, such as in the production of jet engines, missile guidance systems, antimissile defense systems, satellites, and communication systems. Photographs used with permission from https://www.PEXELS.com. 


\section{Rare Earth Elements}

The REEs, also referred to as the lanthanides or lanthanoids, include elements from lanthanum (fig. 2, atomic number 57) to lutetium (atomic number 71) on the periodic table of elements. Promethium $(\mathrm{Pm}$, atomic number $=61)$, is excluded, because it is not naturally occurring. Yttrium $(\mathrm{Y}$, atomic number $=39)$ shares chemical and physical similarities with the lanthanides and thus is often included in the REE group of elements. Scandium $(\mathrm{Sc}$, atomic number $=21)$ is chemically similar to and sometimes included with the REEs. However, scandium does not commonly occur in significant quantities in the same mineral deposits with the lanthanides and yttrium.
The REEs are traditionally divided into two informal groups based on their atomic weight (table 1). Lanthanum through gadolinium (atomic numbers 57 through 64) are grouped as light rare earth elements (LREEs) and terbium through lutetium (atomic numbers 65 through 71) as the heavy rare earth elements (HREE). Some authorities, including the International Union of Pure and Applied Chemistry, include europium and gadolinium within the group of heavy REEs. Yttrium, although atomically light (atomic number 39), is included with the HREE group because it shares common chemical and physical properties with the HREEs. In general, the HREE group is particularly important to emerging technologies, less abundant, and harder to source than the LREEs, and thus command a higher price.

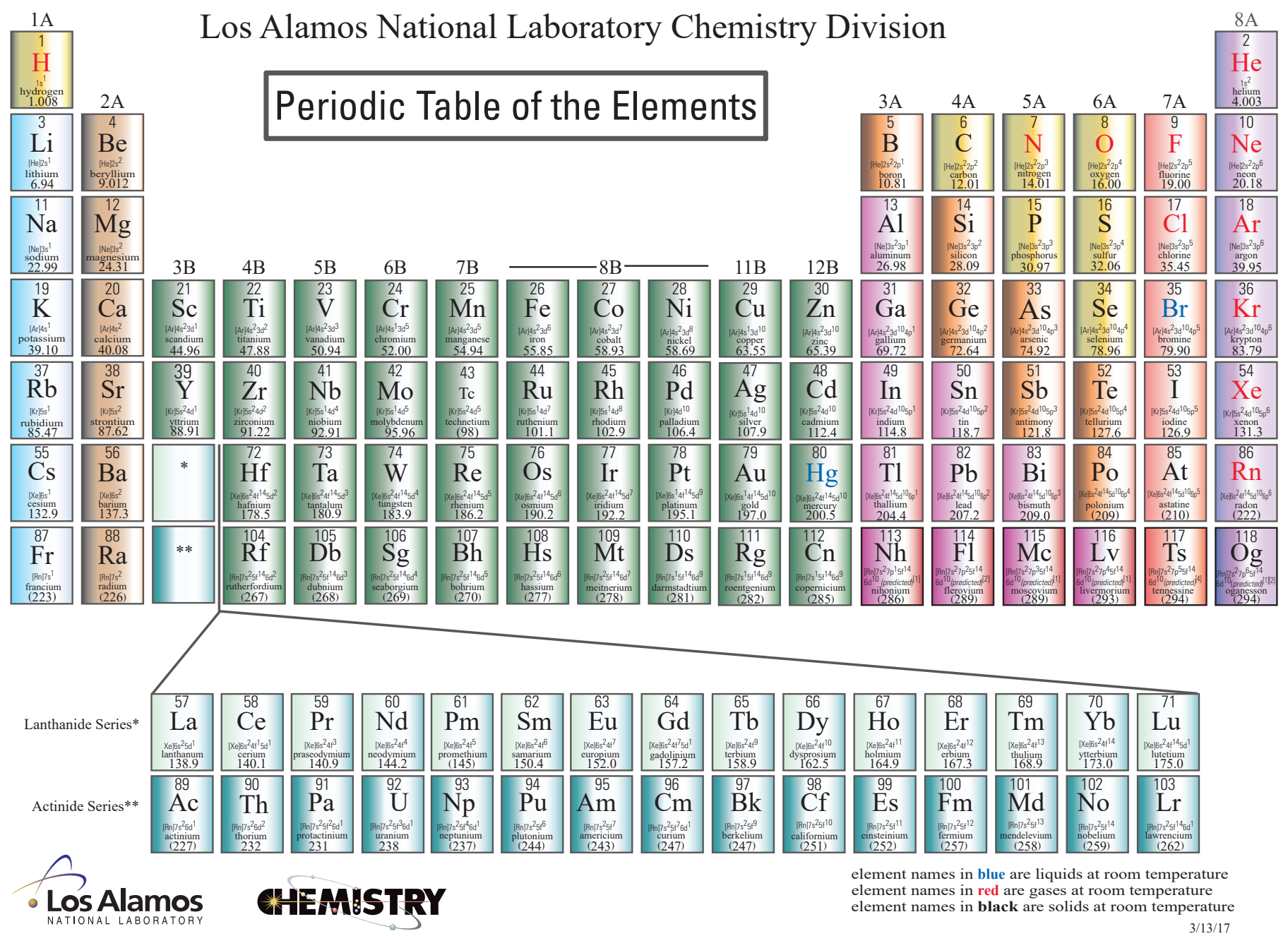

Figure 2. Periodic table of the elements. 
Table 1. Rare earth elements and their applications.

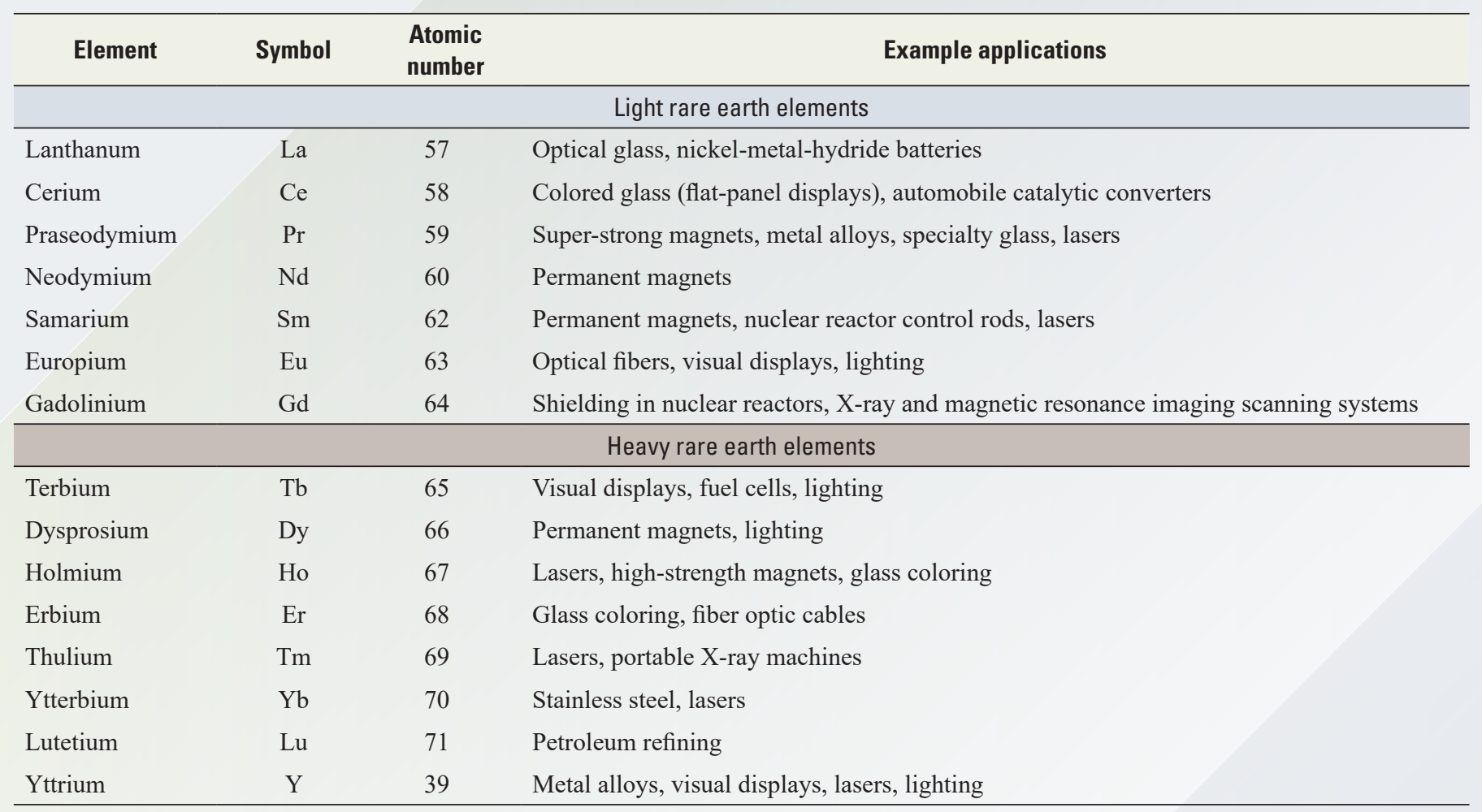

\section{Supply Concerns}

From the mid-1960s to the early 1990s, the United States was the world's largest REE-producing country, with production coming entirely from the Mountain Pass mine in southeastern California (figs. 3 and 4). In the late 1980s, China began mining their in-country REE deposits, processing their ore and extracting and separating the individual REEs for use in products, which they also manufactured. China quickly gained control of global REE production, providing 95 percent of the global market of processed REE by 2011 (fig. 5). Between 2011 and 2017, China produced approximately 84 percent of the world's REEs, followed by Australia with about 8 percent of production (Gambogi, 2019). Within this period, the United States only produced REEs between 2012 and 2015, entirely from the Mountain Pass mine, which contributed only about 4 percent of the world REE supply.

Meeting the growing need for HREEs has been particularly challenging because efforts to identify economically feasible HREE-enriched deposits outside of China have generally been unsuccessful. The world's principal source of HREEs are unusual clay deposits in southern China, which are profitable because of their relatively low-cost mining and chemical extraction methods and less stringent environmental restrictions. A global search for similar clay deposits is ongoing, including the southeastern United States.
Heavy dependence on a single country as a source of the REEs has led to concern from many groups, including high dependence on new electronic, computer, and green technologies by countries such as the United States, Japan, and the European Union. The U.S. Defense Department has expressed these concerns and commissioned studies to evaluate the concentration of the REE supply chain in China (U.S. Government Accountability Office, 2016). These reports emphasize the "criticality" of the recent REEs situation, the limited sources for supply, and the important role of REEs in our modern technologies and economies (National Research Council, 2008; European Commission, 2010; U.S. Department of Energy, 2011). The significant increases in applications and demands for REEs has led to an increased interest in identifying new sources that include extraction from mineral deposits, extraction from coal-based resources, and recycling of products containing REEs. The Department of Energy is currently (2019) evaluating technologies to recover REEs and other critical minerals from coal and coal-based resources (https://www.netl.doe.gov/coal/rare-earth-elements). Recycling efforts have focused on recovering REEs from light bulbs and electronics. In response to these national concerns the U.S. Geological Survey (USGS) has been investigating the REE-bearing mineral deposits in the United States to better inform stakeholders on the characteristics of the domestic, inthe-ground REE resources (Long and others, 2010; Van Gosen and others, 2014a, 2014b, 2017; McCafferty and others, 2014; 


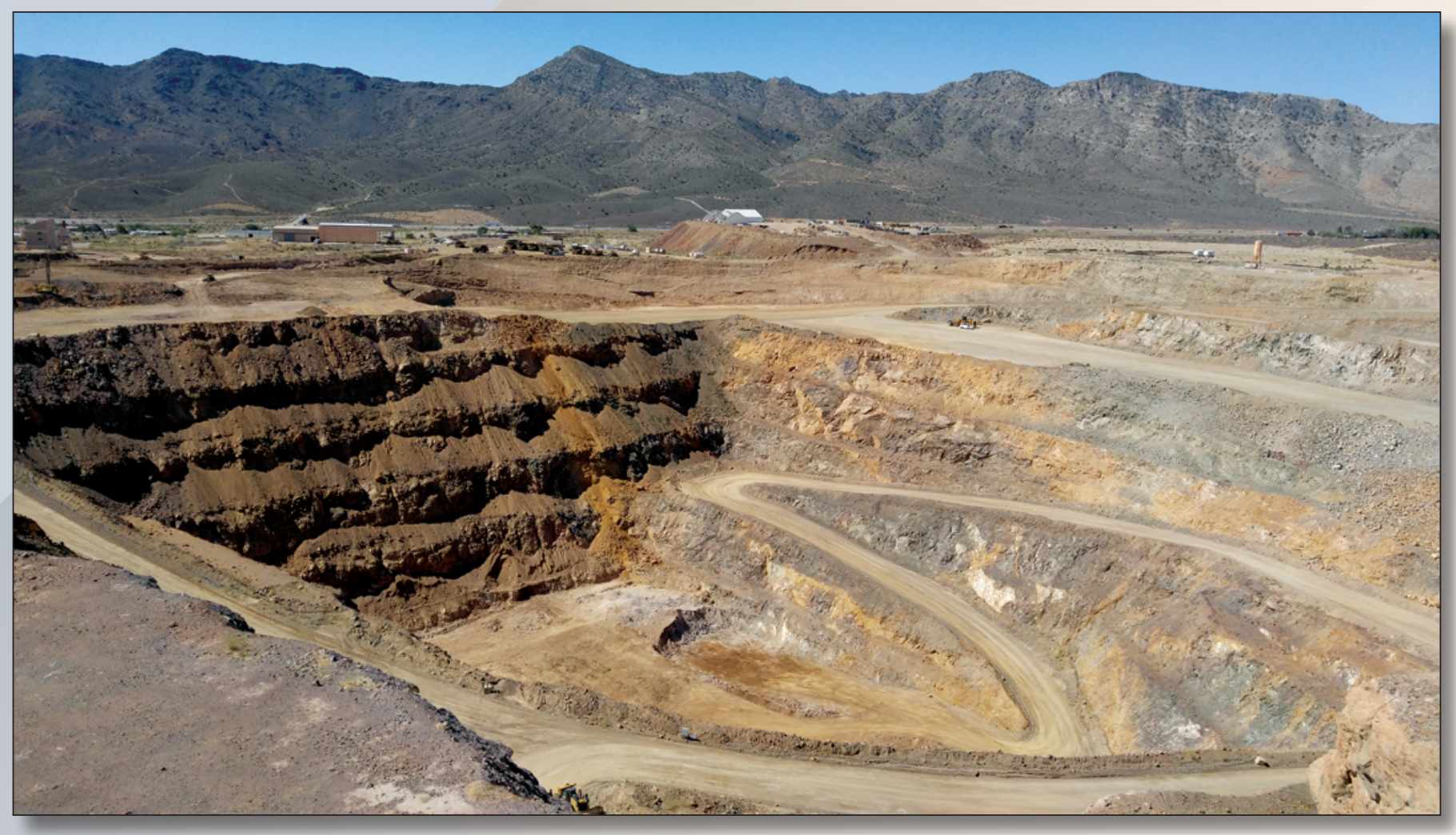

Figure 3. Mountain Pass mine, southeastern California, June 2018. The ore body, called the Sulphide Queen deposit, is a large tabular carbonatite intrusion, thought to be the largest rare earth element deposit in the United States. The deposit was discovered in 1949. Mining of the deposit began in 1952 and continued with nearly continuous production until 2002, resumed from 2012 to 2015, and began again in 2017 under new ownership. Photograph by Bradley Van Gosen.

Verplanck and others, 2014; Emsbo and others, 2015, 2016; Foley and Ayuso, 2015; Day and others, 2016; Hofstra and others, 2016; Karl and others, 2016; Senguta and Van Gosen, 2016; McCullough and Nassar, 2017; Shah and others, 2017; Bellora and others, 2018; Fortier and others, 2018; Dicken and others, 2019; Hammarstrom and Dicken, 2019). This report briefly summarizes the principal types of mineral deposits in the United States known to contain elevated concentrations of the REEs, with examples of each.

\section{Principal Rare Earth Element Minerals in Economic Nonfuel Mineral Deposits}

Although at least 245 individual REE-bearing minerals have been identified, only a few minerals contribute the majority of the REE concentrations in economic nonfuel mineral deposits. These minerals are bastnäesite (also spelled bastnäsite), monazite, and xenotime (table 2; fig. 6). In addition, the phosphate mineral apatite is a potentially important source of REEs because it can contain a substantial amount of REEs due to its crystal structure. These minerals tend to be enriched in either light or heavy REEs, but not equally.
Bastnäesite.-A REE-carbonate-fluorine mineral (table 2), is the main ore mineral in carbonatite REE deposits, including the three largest REE mines, Bayan Obo and Maoniuping deposits in China and the Mountain Pass deposit, California. Because these carbonatite-hosted deposits are the largest global sources of REEs, especially the LREEs, bastnäesite may be considered the most important REE mineral. Bastnäesite commonly occurs with two other REE-carbonatefluorine minerals, synchysite and parisite. Bastnäesite contains up to 75 weight-percent REE oxides and is highly enriched in the LREEs. The separation and processing for bastnäesite is well established. For these reasons, bastnäesite accounts for the majority of the LREE production in the world.

Monazite.-A REE-phosphate mineral (table 2), was the primary REE ore mineral prior to the discovery of bastnäesite-rich deposits. Monazite, the most common REE mineral, occurs in a range of geologic environments and is typically enriched in the LREEs. Historically, monazite was extracted from placer deposits - stream and coastal sediments - because monazite resists chemical and physical weathering and has a relatively high density, allowing it to be transported but not destroyed and ultimately sorted by the actions of water and (or) wind into discrete layers with other heavy minerals in these depositional environments 


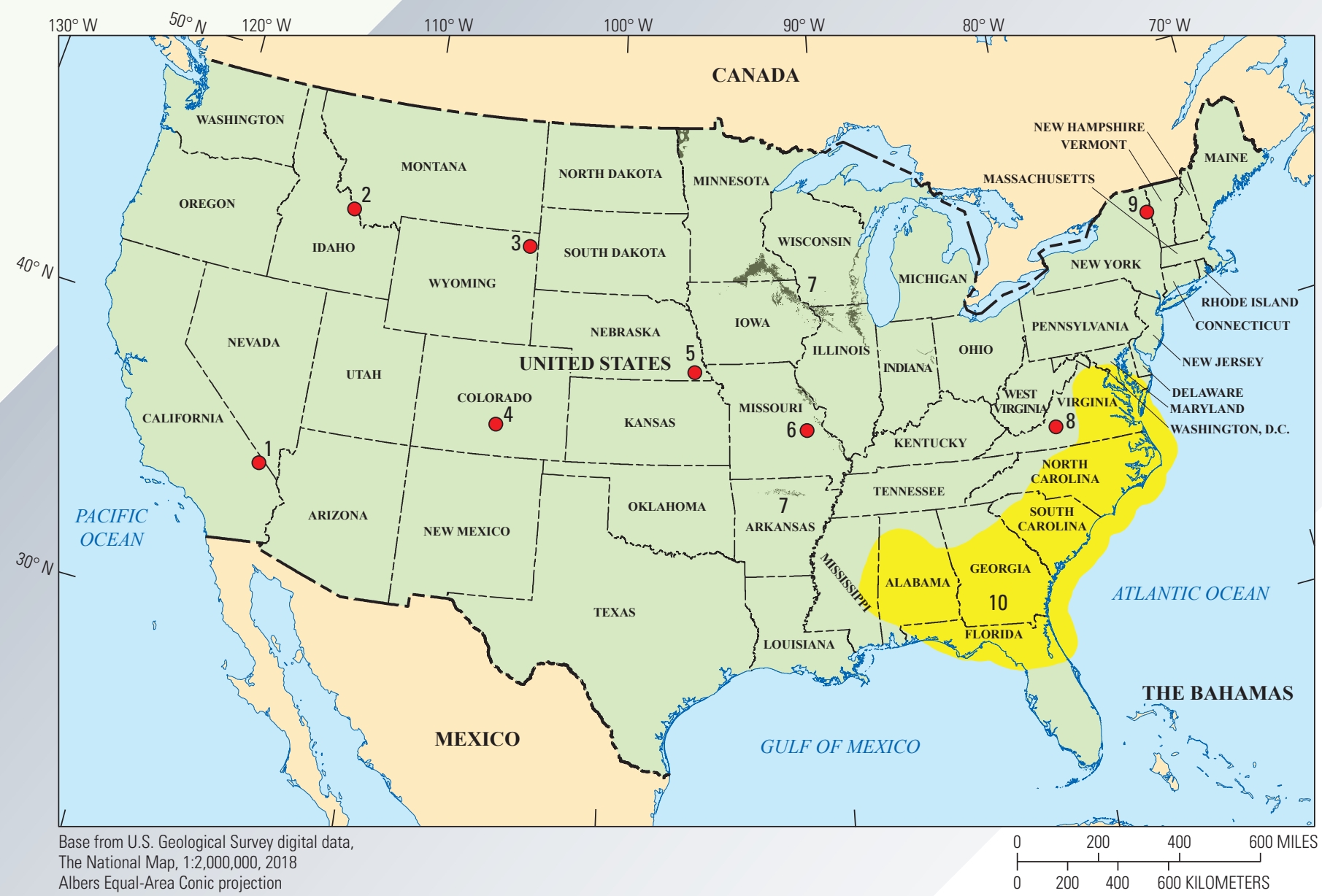

Standard parallels $29^{\circ} 30^{\prime} \mathrm{N}$. and $45^{\circ} 30^{\prime} \mathrm{N}$.

Central meridian $96^{\circ} 30^{\prime} \mathrm{W}$. latitude of origin $23^{\circ} \mathrm{N}$

North American Datum of 1983

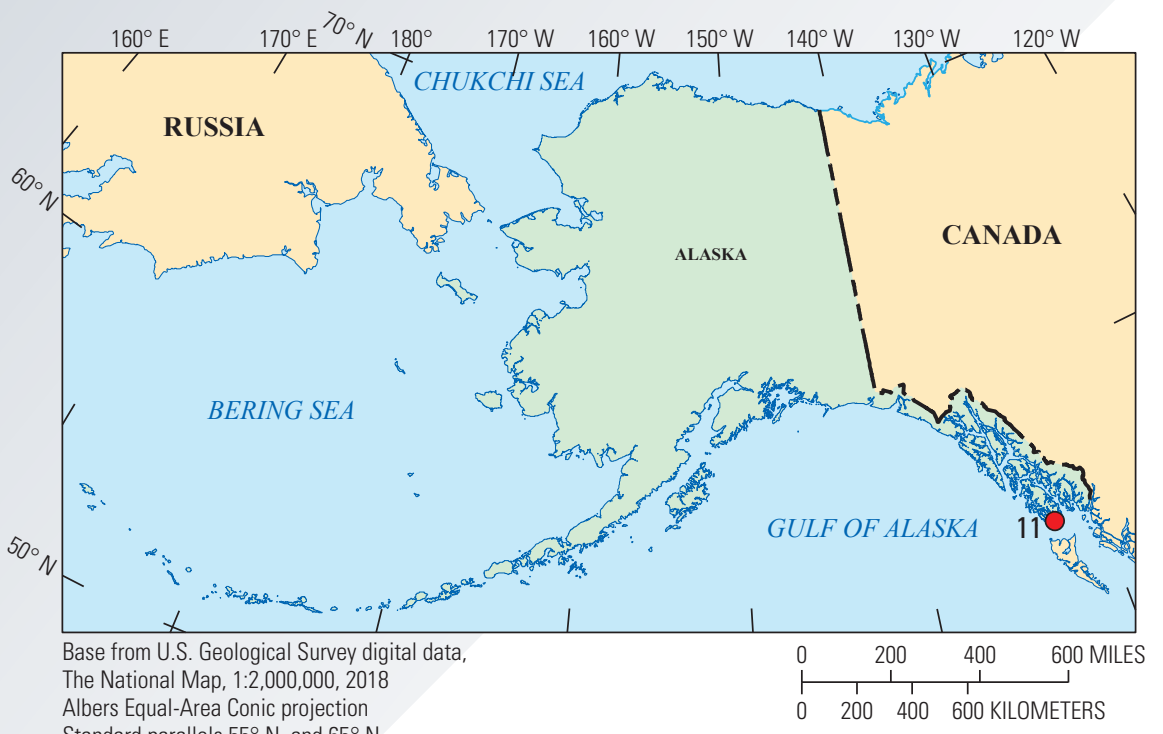

Albers Equal-Area Conic projection

Central meridian $154^{\circ} \mathrm{W}$. latitude of origin $50^{\circ} \mathrm{N}$.

North American Datum of 1983
Figure 4. Rare earth element (REE) deposits in the United States. Numbers on map indicate locations of deposits discussed in this report. 1, Mountain Pass, CaliforniaCarbonatite deposit; 2, Lemhi Pass, Idaho and Montana-REE-bearing veins; 3 , Bear Lodge, Wyoming - Carbonatite deposit; 4, Wet Mountains, Colorado-REE-bearing veins; 5, Elk Creek, Nebraska-Carbonatite deposit; 6, Pea Ridge, Missouri-Iron-oxide apatite deposit (IOA); 7, Upper Ordovician phosphorites (gray areas in Arkansas, Illinois, Indiana, lowa, Minnesota, Missouri, and Wisconsin)—REE-bearing phosphorites; 8, Clay deposits at Stewartsville pluton, Virginia-lon-adsorption clay deposits (REE in granite-derived regolith); 9, Mineville iron mining district, New York-Iron-oxide apatite deposits (IOA); 10, Atlantic Coastal Plain (yellow areas in Maryland, Virginia, North Carolina, South Carolina, Georgia, Florida, and Alabama)-Monazite-Xenotime-bearing placer deposits (heavy-mineral sands); 11, Bokan Mountain, Prince of Wales Island, Alaska-REE-bearing veins in an alkaline igneous complex. 


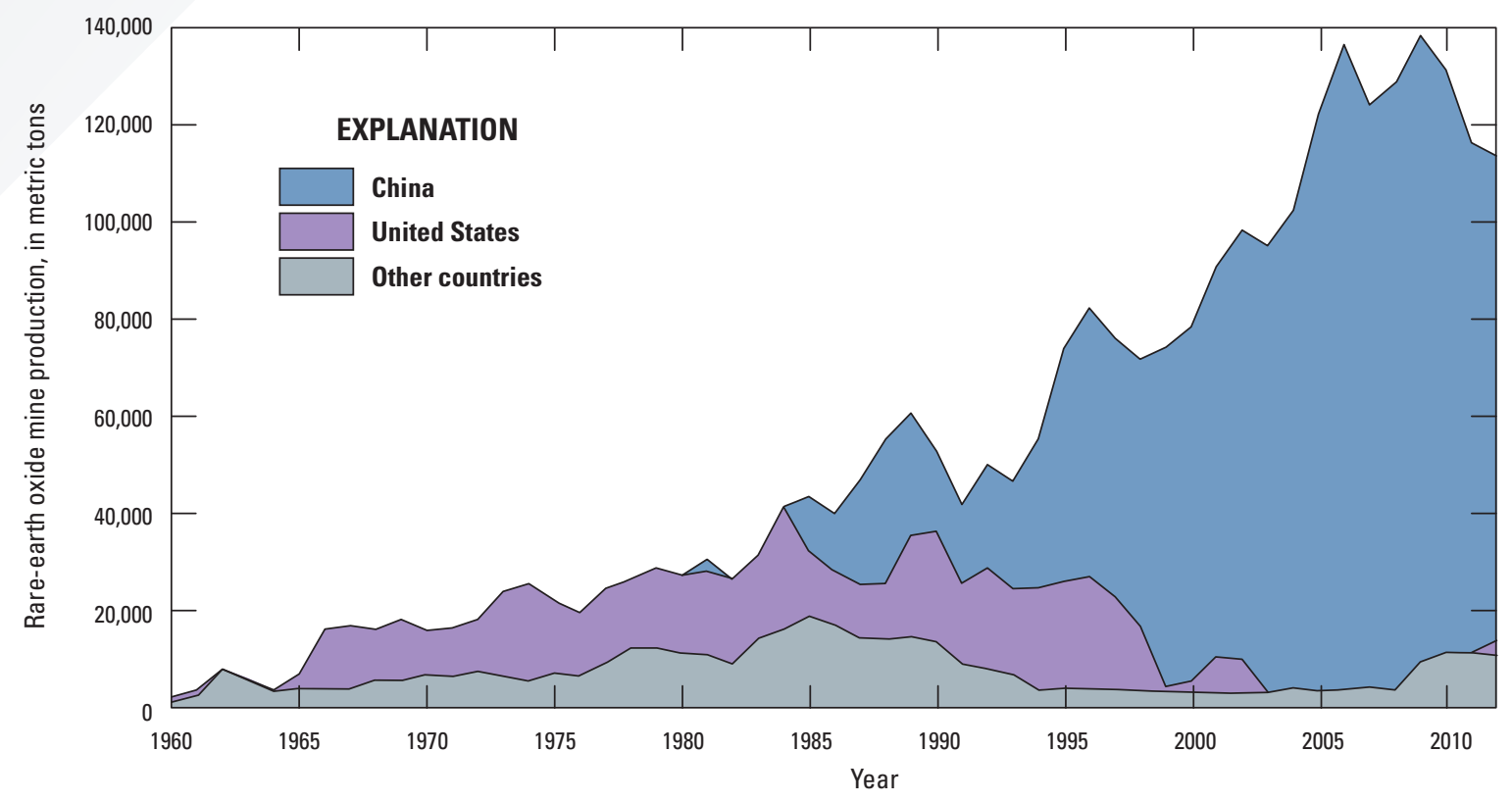

Figure 5. World mine production of rare-earth oxides, by country and year, from 1960 to 2012. The layers of the graph are placed one above the other, forming a cumulative total. Data are from Kelly and Matos, 2014.

(Sengupta and Van Gosen, 2016). Monazite can occur in carbonatite-related REE deposits as a primary mineral phase (crystallized from magma, as in the Mountain Pass deposit) or as a secondary (replacement) mineral in the weathered zone (for example, the carbonatites of Mount Weld, Western Australia, and Araxá, Brazil). The weight percent of REEs within monazite is quite variable depending on what other elements are present. Monazite typically contains small amounts of thorium, making it radioactive.

Xenotime.-A yttrium (Y)-phosphate mineral (table 2), has been a source of REEs as a byproduct commodity in river placer mines. Because yttrium has a similar charge and ionic radius to other HREEs, xenotime generally contains substantial amounts of the HREEs. Xenotime's crystal structure can accommodate significant quantities of uranium and thorium, which can contribute to environmental and handling issues when this mineral is separated and stockpiled, similar to the radioactivity issues associated with monazite. Because xenotime is enriched in the more valuable HREEs, it has become an important exploration target.

Apatite.-A calcium-phosphate mineral (table 2), is an important source of phosphate. It may also contain significant quantities of REEs. Apatite occurs in a range of rock types and can be LREE- or HREE-enriched, although they are most commonly LREE. Apatite may be an important source of REEs in some carbonatites (for example Mushgai Khudag, Mongolia) and iron-oxide apatite deposits (Pea Ridge, Missouri, and Mineville, New York; fig. 4).

\section{Rare Earth Element Mineral Deposit Types in the United States}

REEs are relatively common in the Earth's crust; however, economic concentrations of these elements are not commonplace and the REEs tend to concentrate in uncommon rock types. The generalized characteristics of mineral deposit types that host REE enrichments are briefly described in this section, with selected occurrences in the United States that may have the potential to mitigate the dependence on imported REEs. More detailed discussions on the principal REE deposits and districts of the United States are provided in

Table 2. Principal rare earth element (REE) minerals in various economic REE deposits and their ideal chemical formula.

\begin{tabular}{|c|c|}
\hline Mineral & Formula \\
\hline Bastnäesite & $\mathrm{REECO}_{3} \mathrm{~F}$ \\
\hline Paristite & $\mathrm{CaREE}_{2}\left(\mathrm{CO}_{3}\right)_{3} \mathrm{~F}_{2}$ \\
\hline Synchysite & $\left.\mathrm{CaREE}\left(\mathrm{CO}_{3}\right)_{2} \mathrm{~F}\right)$ \\
\hline Monazite & (REE,Th) $\mathrm{PO}_{4}$ \\
\hline Xenotime & (Y,HREE,Th,U)PO ${ }_{4}$ \\
\hline Apatite & $(\mathrm{Ca}, \mathrm{REE})_{5}\left(\mathrm{PO}_{4}\right)_{3}(\mathrm{~F}, \mathrm{Cl}, \mathrm{OH})$ \\
\hline
\end{tabular}



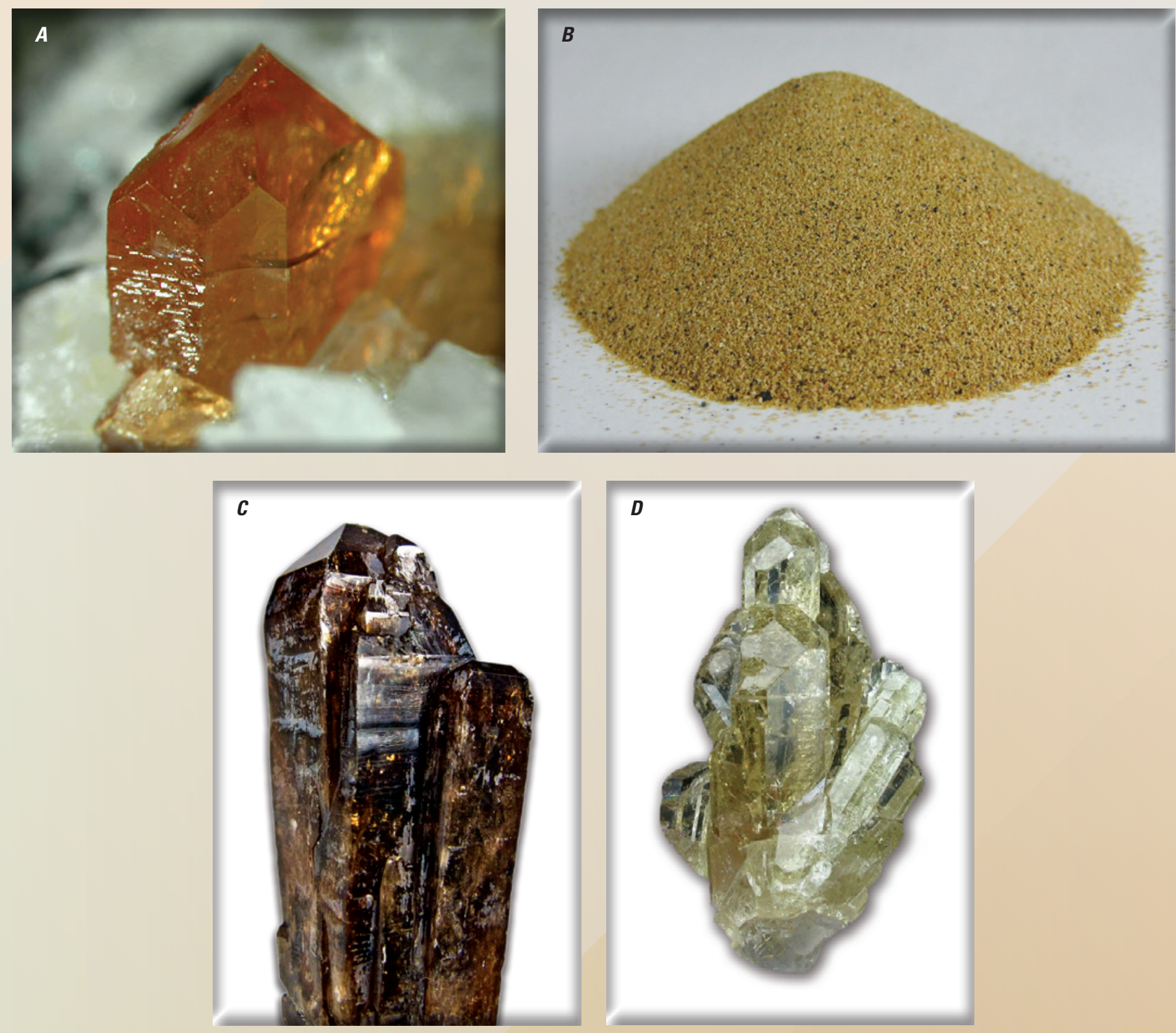

Figure 6. Principal ore minerals recovered for rare earth elements (REE) are bastnäesite, monazite, xenotime, and apatite.

A, Bastnäesite, an REE-carbonate-fluorine mineral, is the primary ore mineral in the world's largest REE deposits, and the principal source of the global LREE supply. Photograph by Rob Lavinsky, https://www.iRocks.com/. $B$, Monazite, an REE-thorium-phosphate mineral, has been separated from ancient and modern beach sands as a coproduct of the recovery of economic titanium minerals. Monazite was the primary REE ore mineral prior to the mining of bastnäesite-rich, hard rock deposits. Photograph from https://geology.com/. C, Xenotime, a yttrium-phosphate mineral, has been a source of REEs as a byproduct commodity in river placer mines. Because yttrium has a similar charge and ionic radius to other heavy rare earth elements (HREE), xenotime generally contains substantial amounts of the HREEs.

Photograph by Rob Lavinsky, https://www.iRocks.com/. D, Fluorine-bearing apatite, a calcium-phosphate mineral. Apatite occurs in a range of rock types and can contain significant quantities of light rare earth elements (LREE) or HREEs, although most commonly LREE. Apatite may be an important source of REEs in some carbonatites and iron-apatite deposits (Pea Ridge, Missouri, and Mineville, New York). Photograph by Rob Lavinsky, https://www.iRocks.com/. 
Long and others (2010), datasets in Bellora and others (2019), and numerous references cited in these reports. Exploration for REE deposits, data on the size and concentrations of REEs (tonnage and grade) in well explored and developed deposits, and environmental considerations in mining of REE deposits are discussed in Van Gosen and others (2017).

\section{Carbonatite REE-Bearing Deposits}

These deposits are hosted in unusual igneous intrusions - carbonatites - that are composed of 50 percent or more carbonate minerals, mainly calcite and dolomite, reflecting carbonate-rich source magmas (Verplanck and others, 2014). Large carbonatite bodies in China (for example, Bayan Obo, Maoniuping, Daluxiang, and Weishan) have been the sources of most of the global REE production for many years. Bastnäesite is the primary REE ore mineral in most carbonatites and can be accompanied by REE-bearing synchysite, parisite, monazite, and apatite, with occasional contributions from secondary xenotime that may form in weathered ore, such as in the Mount Weld deposit in Western Australia. Carbonatites tend to have the highest total REE concentrations of any igneous rocks. While the extraordinarily large carbonatite deposits are proven producers and large enough such that a single deposit can produce much of the world's LREEs demand, they are typically depleted in HREE and, thus incapable of producing significant quantities of the important HREEs.

The Mountain Pass deposit in southeastern California (fig. 3) is the largest known REE deposit in the United States (Verplanck and others, 2014; Van Gosen and others, 2017). This deposit produced most of the REEs mined in the United States since the late 1960s (fig. 5) and contains proven and probable reserves totaling 18.4 million metric tons of carbonatite ore averaging 7.98 percent rare earth oxide (REO) using a cutoff grade of 5 percent REO (Molycorp, Inc., 2012). In 2018, the mine was reopened and is currently (2019) producing a bastnäesite concentrate from the ore body that primarily consists of calcite, dolomite, barite, and bastnäesite in varying proportions.

Other REE-rich carbonatites in the United States include the Bear Lodge deposit in northeastern Wyoming and the Elk Creek deposit in southeastern Nebraska (fig. 4) (Long and others, 2010). The Bear Lodge carbonatite complex has been thoroughly drilled with proven plus probable resources of
15.6 million metric tons of ore averaging 2.78 percent total REO (Rare Element Resources, Ltd., 2015). The Elk Creek deposit is a REE- and niobium-rich carbonatite that lies about 200 meters $(\mathrm{m})$ below the surface; it was discovered in 1970 by a regional airborne geophysical survey (Long and others, 2010). Core drilling into the Elk Creek carbonatite during the 1970s, 1980s, and more recently in the 2010s has identified many intervals containing from 1 to more than 3 percent total REO. Recent (2019) developers of the Elk Creek property (NioCorp Developments, Ltd.) have emphasized the carbonatite's potential resources of niobium, scandium, and titanium.

\section{Alkaline Igneous REE Deposits}

These deposits are hosted in alkaline igneous rocks, another uncommon group of igneous rock that are geochemically characterized by depletion in silica relative to sodium, potassium, and calcium in comparison to "typical," more silica-rich igneous rocks (Verplanck and others, 2014). Deposits in alkaline igneous rocks have been relatively small contributors to the global REE supply, but alkaline-hosted deposits have become important exploration targets, because they tend to be more enriched in the heavy HREEs than carbonatites and most other REE deposit types.

An example of an alkaline igneous-related REE deposit in the United States occurs at Bokan Mountain in a southern part of Prince of Wales Island, southeastern Alaska. The deposit consists of vein-like intrusions (thin dikes) containing REEs, thorium, and uranium concentrations of several percent each. The principal vein-dike system, the Dotson zone, extends for at least 2.6 kilometers $(\mathrm{km})$ in length and is composed of numerous, subparallel, thin dikes that are $1.5 \mathrm{~m}$ or less in width, forming a zone of about $50 \mathrm{~m}$ in total width (fig. 7). The REE mineralogy in these vein dikes is complex and fine-grained, with more than two dozen distinct REE minerals. These REE minerals occur in a variety of types, including oxide, silicate, phosphate, and carbonate minerals. Based on extensive drilling of the Dotson zone and adjacent I and L zone by Ucore Rare Metals Ltd. (Robinson and others, 2011), the vein dikes have a combined inferred resource of 5.275 million metric tons (Mt) of rock averaging 0.262 percent HREE oxides and 0.392 percent LREE oxides (Robinson and others, 2011). 



Figure 7. Outcrop of rare earth element (REE)-rich "vein-dike" intrusions (dark vertical layers) in the Dotson zone on Bokan Mountain, southern part of Prince of Wales Island, southeastern Alaska. The vein-like dikes were emplaced by REE-bearing magmas, and subsequently altered multiple times by heated fluids. These vein dikes contain at least two dozen REE-bearing mineral phases, in forms of silicates, carbonates, phosphates, and oxide minerals. Photographs by Bradley Van Gosen. 


\section{Rare Earth Elements in Sedimentary Phosphate Deposits}

USGS research has discovered that francolite (a carbonate-rich apatite mineral), common to some sedimentary phosphate-rich rocks (phosphorite), is highly enriched in HREEs. A continent-scale assessment has identified several unmined HREE-bearing phosphorites in the United States that are exposed over large areas (Emsbo and others, 2015, 2016). This research has also demonstrated that REEs vary in a secular fashion because of oceanic redox state transitions during specific time periods in Earth's history. The consistency of REE abundances within individual time horizons has identified time periods-Late Mississippian, Devonian, and Ordovician - as particularly favorable for the formation of phosphorites with high-REE abundances. For example, an Upper Ordovician horizon may rank as one of the largest concentrations of HREEs in the world. This nearly horizontal horizon occurs at, or just below the surface, over an area of 2,000 square kilometers $\left(\mathrm{km}^{2}\right)$ in northern Arkansas (fig. 8). Samples from more than $100 \mathrm{~km}^{2}$ of this 1.5 -m-thick horizon have remarkably homogenous REE abundances, estimated to comprise $235 \mathrm{Mt}$ of phosphate rock with $1.3 \mathrm{Mt}$ of extractable total REE, of which $0.37 \mathrm{Mt}$ are HREE, which is nearly twice the HREE content of the south China clays deposits (Emsbo and others, 2015). Moreover, this ore horizon extends in the shallow subsurface throughout Missouri and Indiana. Several samples of thin, irregularly distributed Upper Devonian phosphorites occurrences in the midcontinent region of the central United States reveal high HREE concentrations (orders of magnitude higher than the producing south China deposits).

The REEs in sedimentary phosphorites are nearly

100 percent extractable, using technologies currently (2019) used in the phosphate fertilizer industry in the United States (Emsbo and others, 2015). The scale of the domestic fertilizer industry, which produces 30 million metric tons per year, suggests that byproduct REE production from phosphate mines could meet much of the Nation's HREE demand (Emsbo and others 2015, 2016). Furthermore, the ease of beneficiation and chemical dissolution of sedimentary francolite suggests that higher-grade phosphorite deposits might constitute stand-alone REE deposits.

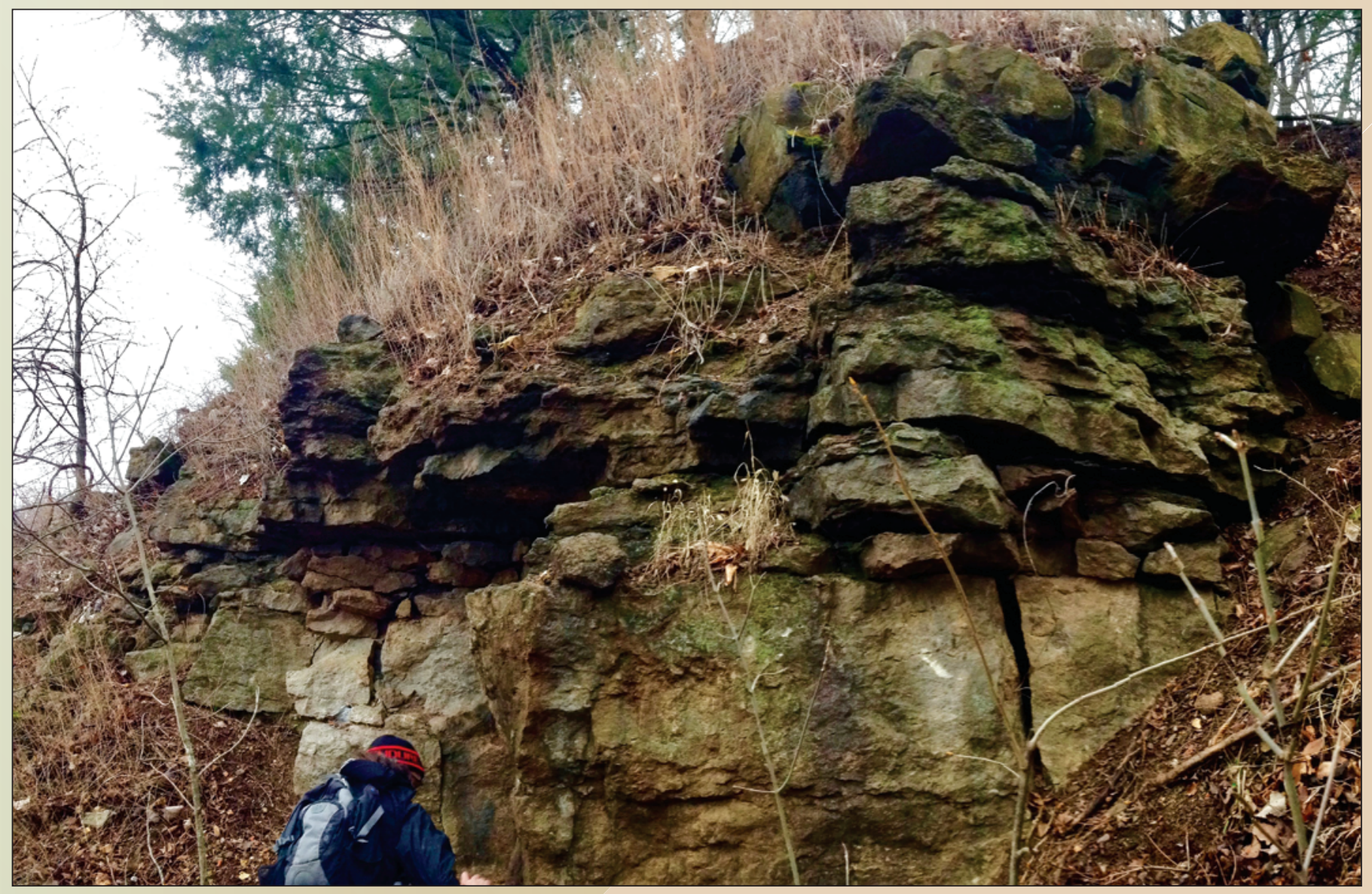

Figure 8. Two-meter-thick outcrop of Upper Ordovician, high-grade REE phosphorite in Arkansas. The unit's thickness and REE concentration is remarkably homogeneous and the unit occurs at, or just below the surface more than 2,000 square kilometers in Arkansas. This phosphorite unit can also be traced into the shallow subsurface into adjacent Missouri and to Indiana. Photograph by Poul Emsbo. 


\section{Vein Deposits}

Mineral districts with multiple REE-rich veins of equivocal origin also exist. Most of these vein deposits are interpreted to be related to alkaline igneous rocks, which are not exposed at the surface and have not been confirmed by drilling. An example of vein-hosted REE mineralization occurs in the Lemhi Pass district along the Montana-Idaho border (fig. 4). This district contains 219 mapped quartz-rich veins with elevated concentrations of REEs and thorium (Staatz, 1979). Most of these veins are made up primarily of quartz and iron-oxide minerals with thorite $\left(\mathrm{ThSiO}_{4}\right)$ and finegrained REE-bearing minerals, including monazite, allanite $\left[(\mathrm{CaCe})\left(\mathrm{Al}_{2} \mathrm{Fe}^{2+}\right)\left(\mathrm{Si}_{2} \mathrm{O}_{7}\right)\left(\mathrm{SiO}_{4}\right) \mathrm{O}(\mathrm{OH})\right]$, and apatite. The veins fill elongate fractures that cut through Precambrian metamorphic rocks. The REE-thorium-rich veins are as much as $1,325 \mathrm{~m}$ in length and $12 \mathrm{~m}$ in width. The veins of the Lemhi Pass district contain approximately equal concentrations of REEs and thorium, with an average REO and thorium content that is about 0.43 percent for each (Staatz, 1979). The underlying source of these veins, most likely alkaline intrusions, is unresolved (Gillerman, 2008). There is little surface evidence of intrusions and no deep drilling has been done in the Lemhi Pass district that could potentially reveal buried intrusions.

The Wet Mountains area of south-central Colorado hosts a district of REE-thorium-rich veins that formed along fractured zones that cut a Precambrian metamorphic terrane (fig. 4) (Armbrustmacher, 1988). The Wet Mountains mineral district is spatially associated with alkaline igneous intrusions, presumed to be genetically related to the REE-thorium veins. Most of these vein deposits lie within a $57 \mathrm{~km}^{2}$ area. The veins and mineralized fracture zones are linear features, typically 1 to $2 \mathrm{~m}$ thick and as much as $15 \mathrm{~m}$ thick. Some veins can be traced for $1.5 \mathrm{~km}$ and some of the fracture zones can be traced for as much as $13 \mathrm{~km}$. The veins and fracture zones average 0.21 percent LREE and 0.14 percent HREE (Armbrustmacher, 1988).

\section{Iron Oxide-Apatite Deposits (IOA)}

Massive iron oxide deposits of magmatic-hydrothermal origin can contain elevated concentrations of REEs, primarily occurring in the mineral apatite. The iron deposits that host elevated REE concentrations are commonly referred to as iron oxide-apatite (IOA) deposits, often considered a subgroup of the more generalized category of iron oxide-copper-gold (IOCG) deposits. Examples of massive IOA deposits in the United States containing enrichments in REEs are the Pea Ridge deposit in southeast Missouri and the Mineville district in northern New York (fig. 4).

The Pea Ridge magnetite-hematite IOA ore body is hosted by Mesoproterozoic volcanic rocks of southeastern Missouri. The magnetite-rich bodies are interpreted as the products of high-temperature, magmatic-hydrothermal processes that may have formed within the root zone of a volcanic caldera. In the Pea Ridge iron deposit, four REE-bearing breccia pipes steeply crosscut the magnetite-hematite orebody and surrounding host rock. Exposed portions of the breccia pipes are as much as $60 \mathrm{~m}$ in horizontal length and as much as $15 \mathrm{~m}$ in width; the pipes extend below the mined levels to an undetermined depth. The primary REE-bearing minerals in the breccia pipes are monazite, xenotime, and a fluorine-rich REE-bearing apatite. As a result, these breccia pipes contain REE of several percent (Day and others, 2016; Hofstra and others, 2016).

Other IOA deposits were mined in the Mineville iron district, New York, located in the northeastern part of the Adirondack Mountains (fig. 4). The ore bodies are massive magnetite deposits intricately folded and faulted within a complex suite of Precambrian metamorphic and igneous rocks. Past mining of the magnetite deposits for iron produced large tailing piles in the Mineville district. Some of the iron ores, and many of the remaining waste rock piles, contain REE-bearing apatite. The REEs reside mainly within apatite in these iron deposits (McKeown and Klemic, 1956). An estimated two-thirds of the district's tailings were derived from apatite-bearing ores, which would represent an estimated 9 million tons of REEbearing tailings. These tailings represent a potential source for yttrium and other HREEs (Staatz and others, 1980).

\section{Monazite-Xenotime-Bearing Placer Deposits (Heavy-Mineral Sands)}

Heavy-mineral sands are sedimentary deposits of dense (heavy) minerals that accumulate with sand, silt, and clay in coastal and alluvial environments, locally forming economic concentrations of heavy minerals (Van Gosen and others, 2014a). Expansive coastal deposits of heavy-mineral sands are the main source of titanium feedstock for the large titanium dioxide pigments industry, through recovery of the minerals ilmenite $\left(\mathrm{Fe}^{2+} \mathrm{TiO}_{3}\right)$, rutile $\left(\mathrm{TiO}_{2}\right)$, and leucoxene (an alteration product of ilmenite). Heavy-mineral sands are also the principal source of zircon $\left(\mathrm{ZrSiO}_{4}\right)$, often recovered as a coproduct, for use mostly in refractory products.

In some deposits, monazite is recovered as a byproduct mineral, sought for its REEs and thorium (Sengupta and Van Gosen, 2016). Monazite is one the heaviest minerals in the heavy-mineral suite and can be the dominant REE- and thorium-bearing mineral in heavy-mineral sands. This monazite is mainly derived from the erosion of igneous and high-grade metamorphic rocks that lie inland of the rivers and coastal plain. Monazite is resistant to chemical and physical weathering, thus can survive the arduous trip from a distant bedrock source to its deposition in a stream, river, or a coastal plain environment.

Byproduct monazite has been recovered in Australia, Brazil, China, Indonesia, Korea, Malaysia, New Zealand, Sri Lanka, Thailand, Zaire, and the United States, derived mainly from the mining of heavy-mineral sands deposits in ancient and modern coastlines, as well as from some inland stream and river (alluvial) deposits. Recently, monazite has been recovered from modern coasts in India, Sri Lanka, and Brazil, and alluvial placers in Malaysia and Thailand (Van Gosen and others, 2014a). 
Recent regional-scale studies of the Atlantic Coastal Plain of the southeastern United States by the USGS have identified (1) areas with elevated concentrations of thorium in coastal sediments, indicative of monazite, based on data measured from regional airborne radiometric surveys (Shah and others, 2017); and (2) areas of high titanium content based on stream sediment sampling surveys across the coastal plain (fig. 4) (Van Gosen and Ellefsen, 2018). These studies suggest that large areas of the Atlantic Coastal Plain are permissive for deposits of titanium-bearing heavy-mineral sands that also contain monazite, a potential source of REEs.

\section{Ion-Adsorption Clay Deposits (REE in Granite- Derived Regolith)}

Clay deposits in southern China are the world's primary sources of the HREEs. This deposit type is informally referred to as south China clay deposits, and more formally as ionadsorption clay deposits or REE in granite-derived regolith. These deposits formed through the intensive weathering of REE-bearing granites in regions that experienced warm climates with moderate to intensive rainfall. The generalized processes that formed these deposits are

- The REEs are leached by groundwater from REEbearing granites (the bedrock).

- Intensive weathering formed thick clay-rich zones of soils (laterite) atop the granites.

- The REEs, sourced from the underlying granite, were mobilized and became weakly attached (by ionadsorption) onto the clays.

- The regions remained stable such that the weathered material is not removed by erosion.

Although these clay deposits typically contain modest REE concentrations (approximately 0.03 to 0.2 percent REEs), they have become economically viable deposits, because (1) they are preferentially enriched in the high-value HREEs; (2) the REEs are easily extracted from the clays with weak acids; and (3) mining costs are low.

A USGS study (Foley and Ayuso, 2015) identified REEbearing clay deposits overlying weathered granite plutons in southeastern United States with several characteristics in common with the south China clay deposits. Comparisons showed similarities in mineralogy, inferred processes of formation, and REE concentrations.

\section{Summary}

Most rare earth elements (REE) deposits tend to be preferentially enriched in either the light rare earth elements (LREE) or the heavy rare earth elements (HREE). Carbonatites, for example, are enriched in minerals of the bastnäesite group, which are LREE rich. Because of this mineralogy, combined with the large size of the world-class carbonatite bodies, they currently fulfill most of the global LREE demand. Coastal deposits of heavy-mineral sands are mined for their titanium minerals, but many also contain accessory grains of monazite, which can be easily extracted from the sands. Monazite is LREE rich and is an additional source of LREEs; however, monazite is more difficult to dissolve and process.

Meeting the growing need for HREEs is more challenging, because efforts to identify additional economically feasible HREE-rich deposits has been less successful. Alkaline igneous intrusions are often more enriched in the HREEs relative to the common igneous rocks, but the ore mineralogy of these deposits can be complex and require specialized mineral separation techniques. Piles of mine-waste materials produced from the past mining of some iron deposits (for example, iron-oxide apatite deposits), specifically the iron ores that contain HREEbearing apatite, may offer another potential secondary HREE resource that has yet to be exploited. U.S. Geological Survey research has also delineated HREE-bearing sedimentary phosphate-rich rocks (phosphorite) that are exposed over large areas of the midcontinent of the United States. Many of these phosphorites are enriched in readily extractable HREEs, thus being a potentially large, but undeveloped HREE resource.

Alaska has considerable potential for undiscovered critical minerals, including REE-bearing deposits. A recent (2016) USGS study used a data-driven, geographic information system (GIS)-implemented method to identify areas that have mineral resource potential in Alaska, which included an evaluation for deposits of REEs with thorium, yttrium, and niobium (and sometimes also uranium and zirconium) associated with peralkaline to carbonatitic igneous intrusive rocks. The prospectivity analysis identified not only areas of known REE-enrichments and prospects, such as the Bokan Mountain peralkaline system and the Tofty carbonatite system, but also highlighted areas with high potential in areas not previously considered to be prospective for REEs. Several of these regions are the focus of ongoing USGS studies to better characterize and interpret the geologic framework and metallogeny for REE mineral potential.

Within the United States many mineral deposits contain concentrations of REEs, but to date, the Mountain Pass mine of southeastern California has been the only substantial producer. The economic development of REE mineral deposits hinges on a variety of factors, which include commodity prices and the entirety of extraction costs. Unlike many traditional metal commodities hosted in relatively simple minerals (as examples, copper in chalcopyrite $[\mathrm{CuFeS}]$ or lead in galena $[\mathrm{PbS}]$ ), most of the REEs are hosted by minerals that have complex chemical formulas, presenting more of a challenge to process and extract the REEs. Furthermore, once the REEs are separated as a group from a mineral, individual REEs must be separated from the other REEs to produce a final product; for example, neodymium is separated from other light REEs for use by the magnet industry. Advancements and refinements in mineral processing techniques may allow mineralogically complex REE deposits to be more readily developed in the future. 


\section{References}

Armbrustmacher, T.J., 1988, Geology and resources of thorium and associated elements in the Wet Mountains area, Fremont and Custer Counties, Colorado: U.S. Geological Survey Professional Paper 1049-F, 34 p., 1 plate. [Also available online at https://doi.org/10.3133/pp1049F.]

Bellora, J.D., Burger, M.H., Van Gosen, B.S., Long, K.R., Carroll, T.R., Schmeda, Germán, and Giles, S.A., 2019, Rare earth element occurrences in the United States (ver. 3.0, March 2019): U.S. Geological Survey data release, accessed April 10, 2019, at https://doi.org/10.5066/F7FN15D1.

Day, W.C., Slack, J.F., Ayuso, R.A., and Seeger, C.M., 2016, Regional geologic and petrologic framework for iron oxide \pm apatite \pm rare earth element and iron oxide copper-gold deposits of the Mesoproterozoic St. Francois Mountains terrane, southeast Missouri, USA: Economic Geology, v. 111, p. 1825-1858, accessed March 13, 2019, at https:// doi.org/10.2113/econgeo.111.8.1825.

Dicken, C.L., Horton, J.D., San Juan, C.A., Anderson, A.K., Ayuso, R.A., Bern, C.R., Bookstrom, A.A., Bradley, D.C., Bultman, M.W., Carter, M.W., Cossette, P.M., Day, W.C., Drenth, B.J., Emsbo, P., Foley, N.K., Frost, T.P., Gettings, M.E., Hammarstrom, J.M., Hayes, T.S., Hofstra, A.H., Hubbard, B.E., John, D.A., Jones, J.V.,III, Kreiner, D.C., Lund, K., McCafferty, A.E., Merchat, A.J., Ponce, D.A., Schulz, K.J., Shah, A.K., Siler, D.L., Taylor, R.D., Vikre, P.G., Walsh, G.J., Woodruff, L.G., and Zurcher, L., 2019, GIS and data tables for focus areas for potential domestic nonfuel sources of rare earth elements: U.S. Geological Survey data release, accessed March 15, 2019, at https:// doi.org/10.5066/P95CHIL0.

Emsbo, Poul, McLaughlin, P.I., Breit, G.N., du Bray, E.A., and Koenig, A.E., 2015, Rare earth elements in sedimentary phosphate deposits - Solution to the global REE crisis?: Gondwana Research, v. 27, p. 776-785, accessed March 13, 2019, at https://doi.org/10.1016/j.gr.2014.10.008.

Emsbo, Poul, McLaughlin, P.I., du Bray, E.A., Anderson, E.D., Vandenbroucke, T.R.A., and Zielinski, 2016, Rare earth elements in sedimentary phosphorite deposits-A global assessment, chap. 5 of Verplanck, P.L, and Hitzman, M.W., eds., Rare earth and critical elements in ore deposits: Reviews in Economic Geology, v. 18, p. 101-114, accessed March 13, 2019, at https://www.segweb.org/store/ detail.aspx?id=EDOCREV18.

European Commission, 2010, Critical raw materials for the EU-Report of the ad-hoc working group on defining critical raw materials: Brussels, Belgium, and Luxembourg, Luxembourg, European Commission, $84 \mathrm{p}$.
Foley, N.K. and Ayuso, R.A., 2015, REE enrichment in granite-derived regolith deposits of the southeastern United States-Prospective source rocks and accumulation processes, in Simandl, G.J., and Neetz, M., eds, Symposium on Strategic and Critical Materials Proceedings, November 13-14, 2015, Victoria, British Columbia: British Columbia Ministry of Energy and Mines, British Columbia Geological Survey Paper 2015-3, p. 131-138, accessed March 13, 2019, at https://www2.gov.bc.ca/gov/content/industry/ mineral-exploration-mining/british-columbia-geologicalsurvey/publications/papers.

Fortier, S.M., Nassar, N.T., Lederer, G.W., Brainard, Jamie, Gambogi, Joseph, and McCullough, E.A., 2018, Draft critical mineral list-Summary of methodology and background information-U.S. Geological Survey technical input document in response to Secretarial Order No. 3359: U.S. Geological Survey Open-File Report 2018-1021, 15 p., accessed March 19, 2019, at https://pubs.er.usgs.gov/ publication/ofr20181021.

Gambogi, Joseph, 2019, Rare earths-Statistics and information: U.S. Geological Survey National Minerals Information Center Web page, accessed March 13, 2019, at https://minerals.usgs.gov/minerals/pubs/commodity/ rare_earths/.

Gillerman, V.S., 2008, Geochronology of iron oxide-copperthorium-REE mineralization in Proterozoic rocks at Lemhi Pass, Idaho, and a comparison to copper-cobalt ores, Blackbird Mining District, Idaho-Final technical report to U.S. Geological Survey, Grant 06HQGR0170: Moscow, Idaho, Idaho Geological Survey, 148 p, accessed March 13, 2019, at https://minerals.usgs.gov/mrerp/Gillerman06HQGR0170.pdf.

Goonan, T.G., 2011, Rare earth elements-End use and recyclability: U.S. Geological Survey Scientific Investigations Report 2011-5094, 15 p. [Also available at https:// pubs.usgs.gov/sir/2011/5094/.]

Hammarstrom, J.H., and Dicken, C.L., 2019, Focus areas for data acquisition for potential domestic sources of critical minerals - Rare earth elements, chap. A of U.S. Geological Survey, Focus areas for data acquisition for potential domestic sources of critical minerals: U.S. Geological Survey Open-File Report 2019-1023, 11 p., accessed March 15, 2019, at https://doi.org/10.3133/ofr20191023A.

Hofstra, A.H., Meighan, C.J., Song, Xinyu, Samson, Iain, Marsh, E.E., Lowers, H.A., Emsbo, Poul, and Hunt, A.G., 2016, Mineral thermometry and fluid inclusion studies of the Pea Ridge iron oxide-apatite-rare earth element deposit, Mesoproterozoic St. Francois Mountains terrane, southeast Missouri, USA: Economic Geology, v. 111, p. 1985-2016, accessed March13, 2019, at https://doi.org/10.2113/ econgeo.111.8.1985. 
Karl, S.M., Jones, J.V., III, and Hayes, T.S., eds., 2016, GIS-based identification of areas that have resource potential for critical minerals in six selected groups of deposit types in Alaska: U.S. Geological Survey Open-File Report 2016-1191, 99 p., 5 appendixes, 12 plates, scale 1:10,500,000, https://dx.doi.org/10.3133/ofr20161191.

Kelly, T.D., and Matos, G.R., comps., 2014, Historical statistics for mineral and material commodities in the United States (2016 version): U.S. Geological Survey Data Series 140, accessed March 15, 2019, at https://minerals.usgs.gov/ minerals/pubs/historical-statistics/.

Long, K.R., Van Gosen, B.S., Foley, N.K., and Cordier, Daniel, 2010, The principal rare earth elements deposits of the United States-A summary of domestic deposits and a global perspective: U.S. Geological Survey Scientific Investigations Report 2010-5220, 96 p., accessed March 13, 2019, at https://pubs.er.usgs.gov/publication/sir20105220.

McCafferty, A.E., Stoeser, D.B., and Van Gosen, B.S., 2014, Geophysical interpretation of $\mathrm{U}, \mathrm{Th}$, and rare earth element mineralization of the Bokan Mountain peralkaline granite complex, Prince of Wales Island, southeast Alaska: Interpretation, v. 2, no. 4, p. SJ47-SJ63, accessed March 13, 2019, at https://library.seg.org/toc/inteio/2/4.

McCullough, Erin, and Nassar, N.T., 2017, Assessment of critical minerals - Updated application of an earlywarning screening methodology: Mineral Economics, v. 30, p. 257-272, accessed March 13, 2019, at https:// link.springer.com/article/10.1007\%2Fs13563-017-0119-6.

McKeown, F.A., and Klemic, Harry, 1956, Rare-earth-bearing apatite at Mineville, Essex County, New York: U.S. Geological Survey Bulletin 1046-B, p. 9-23.

Molycorp, Inc., 2012, Molycorp's rare earth reserves at Mountain Pass increase by 36\%: Molycorp Press Release, April 9, 2012, accessed March 19, 2019, at https:// us 1.campaign-archive.com/?u=a9e8676e 87 fad 805702 b9856 $4 \& \mathrm{id}=8 \mathrm{bad} 5 \mathrm{e} 9295 \& \mathrm{e}=\% 5 \mathrm{BUNIQID} \% 5 \mathrm{D}$.

National Research Council, 2008, Minerals, critical minerals, and the U.S. economy-Committee on Critical Mineral Impacts on the U.S. Economy, Committee on Earth Resources, Board on Earth Sciences and Resources, Division on Earth and Life Studies, National Research Council of the National Academies: Washington, D.C., National Academies Press, 264 p.

Rare Element Resources, Ltd., 2015, Bear Lodge critical rare earth project, northeast Wyoming: Rare Element Resources Fact Sheet, October 2015, accessed March 13, 2019, at http://www.rareelementresources.com/bear-lodge-project/ bear-lodge-project-fact-sheet\#.XIlpkSJKjct.
Robinson, R.J., Power, M.A., Aurora Geosciences (Alaska) Ltd., Barker, J.C., and Cathedral Rock Enterprises, LLC, 2011, Technical report on the exploration program and mineral resource estimate for the Bokan Mountain Property, Prince of Wales Island, Alaska: Ucore Rare Metals, Inc., NI 43-101 Report, 190 p., accessed March 13, 2019, at http:// ucore.com/projects/bokan-mountain-alaska/43-101.

Sengupta, Debashish, and Van Gosen, B.S., 2016, Placer-type rare earth element deposits, chap. 4 of Verplanck, P.L, and Hitzman, M.W., eds., Rare earth and critical elements in ore deposits: Reviews in Economic Geology, v. 18, p. 81-100, accessed March 13, 2019, at https://www.segweb.org/store/ detail.aspx?id=EDOCREV18.

Shah, A.K., Bern, C.R., Van Gosen, B.S., Daniels, D.L., Benzel, W.M., Budahn, J.R., Ellefsen, K.J., Karst, A., and Davis, R., 2017, Rare earth mineral potential in the southeastern U.S. Coastal Plain from integrated geophysical, geochemical, and geological approaches: Geological Society of America Bulletin, v. 129, p. 1140-1157, accessed March 13, 2019, at https://pubs.geoscienceworld.org/gsa/gsabulletin/ article-abstract/129/9-10/1140/207600/rare-earth-mineralpotential-in-the-southeastern-u?redirectedFrom=fulltext.

Staatz, M.H., 1979, Geology and mineral resources of the Lemhi Pass thorium district, Idaho and Montana: U.S. Geological Survey Professional Paper 1049-A, 90 p. [Also available at https://pubs.er.usgs.gov/publication/pp1049A.

Staatz, M.H., Hall, R.B., Macke, D.L., Armbrustmacher, T.J., and Brownfield, I.K., 1980, Thorium resources of selected regions in the United States: U.S. Geological Survey Circular 824, 32 p. [Also available at https://pubs.usgs.gov/ circ/1980/0824/report.pdf.]

U.S. Department of Energy, 2011, Critical materials strategy: Washington, D.C., U.S. Department of Energy, 196 p., accessed March 13, 2019, at https://energy.gov/sites/prod/ files/DOE_CMS2011_FINAL_Full.pdf.

U.S. Government Accountability Office (GAO), 2016, Rare earth materials - Developing a comprehensive approach could help DOD better manage national security risks in the supply chain: U.S. Government Accountability Office Report to Congressional Committees, February 2016, GAO-16-161, 40 p., accessed March 19, 2019, at https:// www.gao.gov/assets/680/675165.pdf.

Van Gosen, B.S., Fey, D.L., Shah, A.K., Verplanck, P.L., and Hoefen, T.M., 2014a, Deposit model for heavy-mineral sands in coastal environments: U.S. Geological Survey Scientific Investigations Report 2010-5070-L, 51 p., accessed March 19, 2019, at http://dx.doi.org/10.3133/sir20105070L. 
Van Gosen, B.S., Verplanck, P.L., Long, K.R., Gambogi, Joseph, and Seal, R.R., II, 2014b, The rare-earth elementsVital to modern technologies and lifestyles: U.S. Geological Survey Fact Sheet 2014-3078, 4 p., accessed March 19, 2019, at https://dx.doi.org/10.3133/fs20143078.

Van Gosen, B.S., Verplanck, P.L., Seal, R.R., II, Long, K.R., and Gambogi, Joseph, 2017, Rare-earth elements, chap. O of Schulz, K.J., DeYoung, J.H., Jr., Seal, R.R., II, and Bradley, D.C., eds., Critical mineral resources of the United States-Economic and environmental geology and prospects for future supply: U.S. Geological Survey Professional Paper 1802, p. O1-O31, https://pubs.er.usgs.gov/publication/ pp1802.

Van Gosen, B.S, and Ellefsen, K.J., 2018, Titanium mineral resources in heavy-mineral sands in the Atlantic coastal plain of the southeastern United States: U.S. Geological Survey Scientific Investigations Report 2018-5045, 32 p., accessed March 13, 2019, at https://pubs.er.usgs.gov/ publication/sir20185045.

Verplanck, P.L., Van Gosen, B.S., Seal, R.R, and McCafferty, A.E., 2014, A deposit model for carbonatite and peralkaline intrusion-related rare earth element deposits: U.S.

Geological Survey Scientific Investigations Report 20105070-J, 58 p., http://dx.doi.org/10.3133/sir20105070J

Publishing support provided by the Science Publishing Network, Denver Publishing Service Center

For more information concerning the research in this report, contact

Mineral Resources Program Coordinator

U.S. Geological Survey

913 National Center

Reston, VA 20192

Telephone: 703-648-6100

Email: minerals@usgs.gov

Home page: https://minerals.usgs.gov 



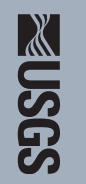

$2 x+1.6$

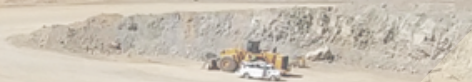

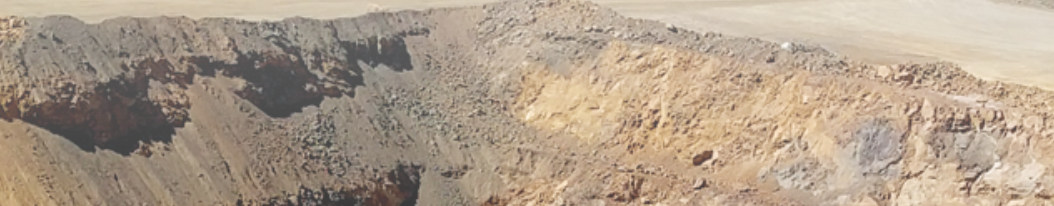

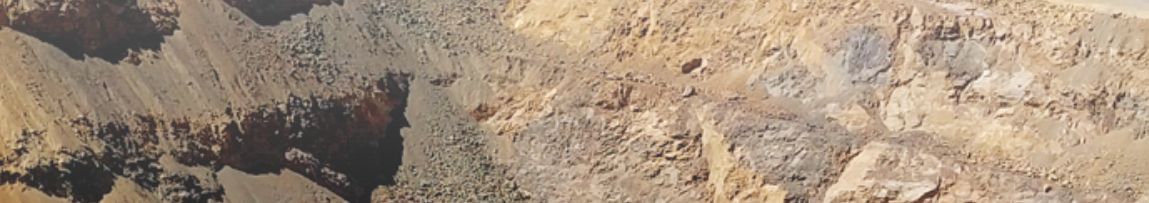

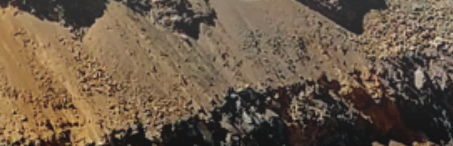



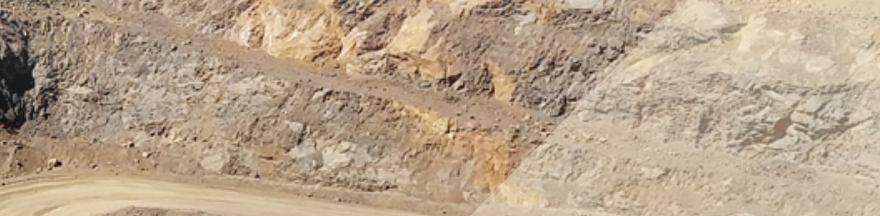
$20-20120$
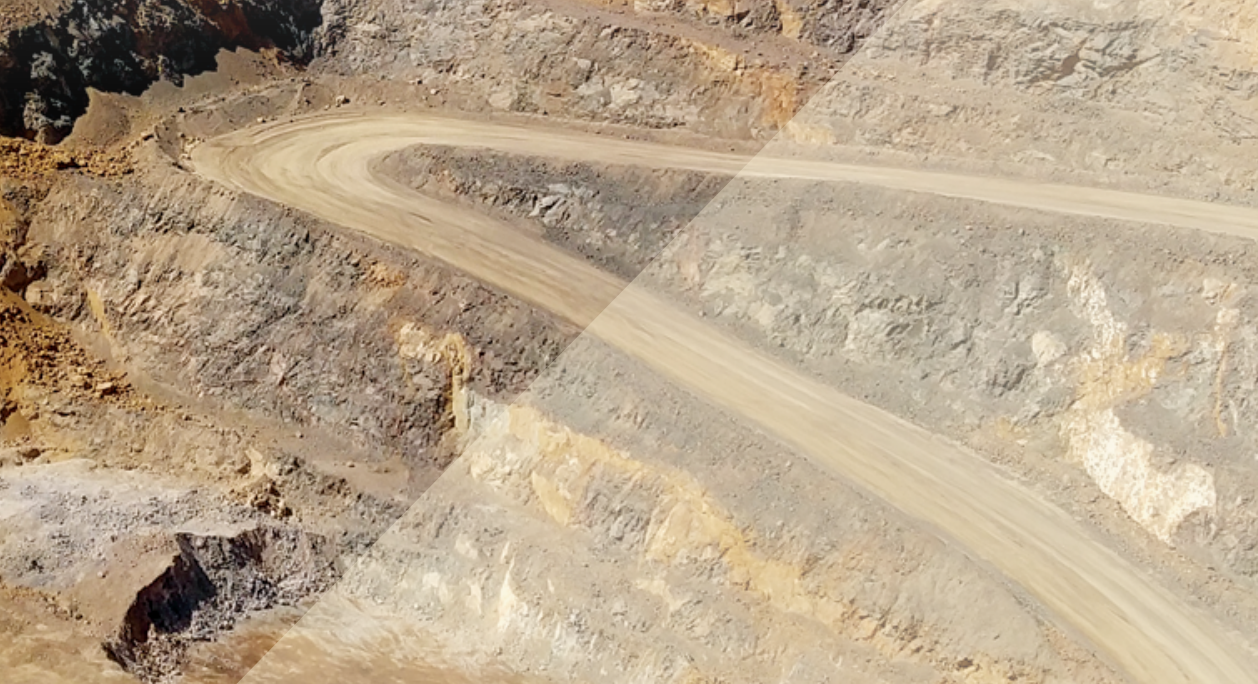

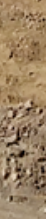
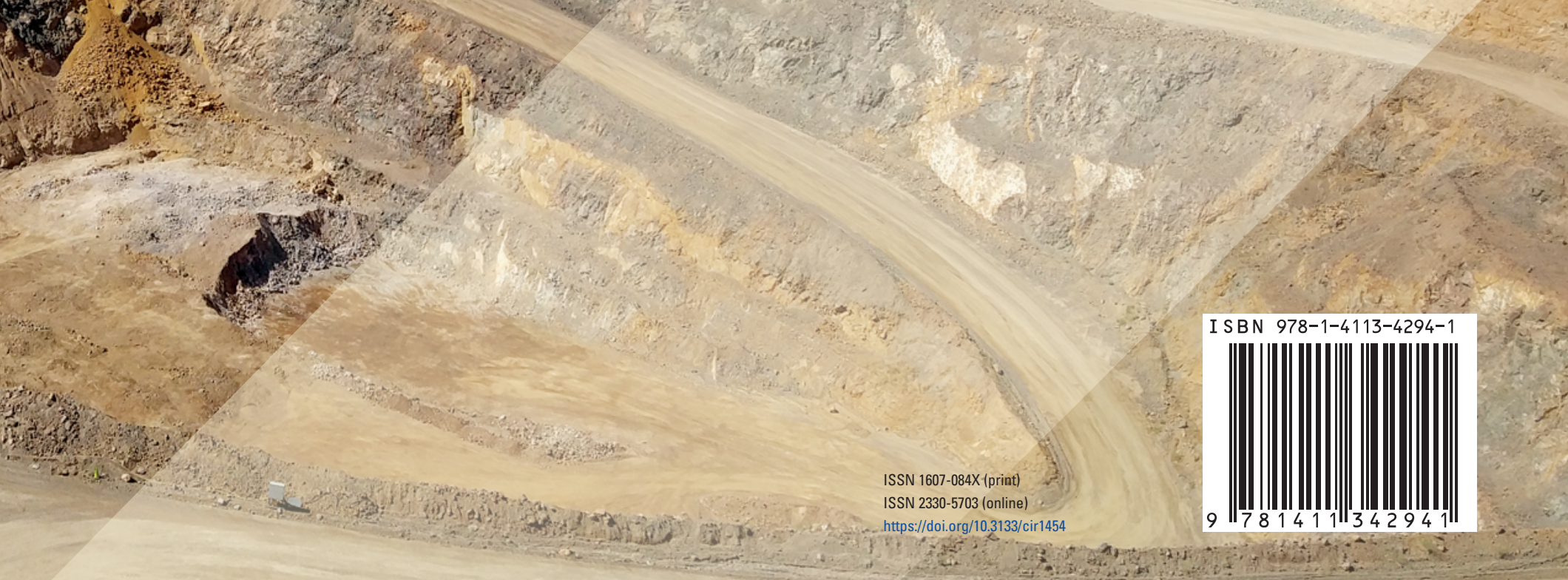

45 